\title{
CONSIDERACIONES SOBRE EL USO Y ABUSO DE LA IMAGEN EN LA PENÍNSULA IBÉRICA EN EL SIGLO XVI A TRAVÉS DE LOS PROCESOS INQUISITORIALES. UNA VISIÓN MULTICULTURAL DEL ARTE: MORISCOS, PROTESTANTES Y CRISTIANOS VIEJOS*
}

Borja Franco Llopis**

"Ahí donde haya seres humanos, no hay mucha distancia del uso al abuso; y la reparación de éste exige una prudencia exquisita"1.

El profesor Míkel de Epalza fue uno de los investigadores más pluridisciplinares que nos ha legado la historiografía hispánica. En sus estudios trató temas de muy diversa índole con metodologías variopintas: moriscos, cristianos viejos, judíos, herejes... fueron analizados con ahínco y perspicacia en sus textos. El arte, como medio difusor de una ideología, también fue un aspecto que le preocupó y gracias al cual entramos en contacto con él hace unos años. Epalza nos animó a adentrarnos en el complicado mundo de la imagen y la evangelización, dándonos pistas de por dónde encauzar nuestra tesis doctoral. Él era bien consciente de que una misma representación podía tener un significado distinto dependiendo del espectador, del bagaje cultural y religioso de aquel que se dedicara a su disfrute o veneración. En nuestro artículo queremos

* Este trabajo se ha realizado gracias a la beca posdoctoral de la Casa de Velázquez, dentro del Proyecto de Investigación I+D+I HAR2009-07740 del Ministerio de Educación y Ciencia: $L a$ configuración de la Pintura Mediterránea del primer Renacimiento en la Corona de Aragón (c. 14351540). Problemas de pintura. Investigador Principal: Dr. Ximo Company Climent.

** Universitat de València.

1. Cfr. A. Silva, Tomás Moro. Un hombre para todas las horas, Madrid, 2007, p. 42. 
hacer una aproximación a la sociología de la imagen partiendo de los documentos inquisitoriales. Si el profesor Epalza trató de situar la figura de Jesucristo entre cristianos, musulmanes y judíos ${ }^{2}$, nosotros intentaremos relacionar las representaciones artísticas con la actitud de los protestantes, moriscos y cristianos viejos ante ellas, viendo cómo reaccionaron cada uno de estos colectivos religiosos frente a la imposición de culto por parte del poder político y religioso, partiendo, principalmente, de la documentación inquisitorial conservada en el Archivo Histórico Nacional de Madrid, una fuente muy utilizada por los historiadores pero que, desde el punto de vista artístico, aún resta en estado virginal, de ahí la importancia de nuestra aproximación.

El tema del Santo Oficio y su repercusión en la sociedad hispánica de la Edad Moderna ha sido uno de los más recurrentes en el estudio de la historia de las mentalidades en dicho periodo. No es nuestra intención desarrollar aquí un planteamiento analítico de cuáles fueron sus orígenes o cómo funcionó durante el siglo XVI, sino extraer de sus procesos y autos de fe todos aquellos aspectos que nos ayuden a comprender el papel que tuvo la imagen dentro de la sociedad y religiosidad moderna con el fin de realizar un estudio detenido de la teoría artística contenida en ellos, tomándolos como punto de referencia y análisis.

Como es bien sabido, el papel de la Inquisición fue el de mantener la ortodoxia de la fe a rajatabla, tratando de evitar cualquier desviación frente a los cánones impuestos por la Iglesia, sobre todo tras el Concilio de Trento. Dentro de esta búsqueda de la ortodoxia el arte fue uno de los elementos más importantes por distintas razones. En primer lugar porque el hecho de no poseer ninguna representación artística en casa podría ser sinónimo de actitud herética, ya que era costumbre, e incluso obligación, en el caso de los moriscos, que tuvieran imágenes de culto privado en sus moradas ${ }^{3}$. Por ejemplo, en el proceso contra Juana Benita Pallas una de las causas que se anota como motivo de acusación y condena es que: "en los aposentos no se ha hallado imagen de santo ni santa, ni mesa, ni silla, ni cama ni colchón"구 $\mathrm{O}$, viceversa, el hecho

2. Míkel de EpalzA, Jesús entre judíos, cristianos y musulmanes hispanos (siglos VI-XVII), Granada, 1999.

3. El obispo de Segorbe, Feliciano de Figueroa (1599-1609), en las Constituciones de su diócesis, obligó a que: "Tengan [los fieles y moriscos] una cruz e imágenes de santos, en sus aposentos, todo el año, con mucha decencia y veneración". Cfr. Pere SABORIT BADENES, «El obispo Figueroa y la evangelización de los moriscos», Anales Valentinos. Revista de filosofía y teología, 44, 1996, p. 435. Esta obligación también se dio en otros obispados, como en el de Granada con Hernando de Talavera (1428-1507), por citar otro ejemplo significativo.

4. AHN. Inquisición. Leg. 557. Núm. 16, 1587. Esta denuncia la podemos ver repetida en el proceso de María Ferrer, morisca vieja de Córdoba: “Doña Leonor de Valderrama doncella por casar hija de Luis de Toledo [...] que abria seys años que aviendo llebado una morisca conocida suya que se llamava Catalina de Abalos una ymagen de Nuestra Señora a su casa teniendola alli avia entrado otra morisca vieja que se llamava Maria Ferrer y la avia reprendido porque tenia allí la otra ymagen diciendola que porque tenia alli aquello no lo aviendo tenido sus padres ni abuelos", siendo pues, procesada esta última al mostrar su desacuerdo con la posesión de estas obras en casa propia. AHN. Inquisición. Leg. 4972. Núm. 6, 1593. 
de rendirles culto se consideró factor principal para dictaminar su absolución, como ocurrió en el caso en el que el reo valenciano afirmó: "hago obras hoyendo missa con devocion, rezando delante las imagines de Nuestro Señor y santos y confessando y comulgando" ${ }^{\prime \prime}$.

A pesar de que es conocido entre los historiadores del arte este tipo de mandatos y obligaciones son pocos los que se han adentrado en el escabroso y complicado mundo de analizar de modo diacrónico y detenido qué aspectos de la teoría artística del Quinientos se plasmaron a través de las más variopintas denuncias y procesos inquisitoriales ${ }^{6}$. Marías, en su estudio sobre los usos artísticos del Renacimiento, fue pionero en esta aproximación, si bien fue de modo muy transversal dentro de su producción científica. Este investigador rescató una normativa, probablemente escrita por el jesuita Juan de Mariana en 1583, que pudo servir de modelo para los diversos tribunales hispánicos a la hora de juzgar a los reos donde se prohibían "todas qualesquer imágenes, retratos, figuras, monedas, empresas, invenciones, maxcaradas, representaciones y medallas, en cualquiera materia que estén estampadas, pintadas, debuxadas, labradas, texidas, figuradas o hechas que sean irrisión de los santos y en desacato e irreverencia suya y de sus imágenes y reliquias o milagros, hábito, profesión o vida. Y así mesmo las que fueren en desacato de la Santa Sede Apostólica, de los Romanos Pontífices, Cardenales y Obispos y de su estado, orden, dignidad y autoridad, claves y poderío espiritual" ${ }^{7}$. Esta pseudolegislación, según el propio Marías, no fue llevada a rajatabla como demuestra la falta de denuncias al respecto ${ }^{8}$.

Si bien el citado historiador está parcialmente en lo cierto, esto es, que el tema de las imágenes ocupa un lugar marginal dentro de la gran cantidad de procesos realizados durante la larga vida del Santo Oficio, no podemos obviar que muchas de las ideas que se arrojaron en sus páginas son fundamentales para conocer las preocupaciones de los habitantes de aquel periodo: católicos, protestantes o moriscos, tal y como les mostraremos en estas páginas. Actitudes dubitativas en cuanto al culto que se le debía rendir a los santos, la Virgen y la cruz se mezclan con otras posturas más beligerantes, que apelan a la destrucción de la imagen como toma de posición y negación del culto que desde la Iglesia romana se estuvo imponiendo con la intención de triunfar ante los movimientos heréticos o disidentes que fermentaron a su alrededor.

Debemos partir de la base de que no todos los colectivos religiosos anteriormente citados tuvieron una misma consideración por parte del poder. Este

5. AHN. Inquisición. Leg. 533. Núm. 12, 1572.

6. Tenemos constancia de que en el transcurso de escritura y publicación de este texto, el profesor Felipe Pereda posee diversos artículos en prensa en los que aborda dichos aspectos, cuya aportación será fundamental para un mejor conocimiento de este asunto.

7. Cfr. Fernando MaríAs, El siglo XVI. Gótico y Renacimiento, Madrid, 1992, p. 187.

8. Esta apreciación la hace en el estudio anteriormente citado (p. 187) así como en El largo siglo XVI: los usos artísticos del Renacimiento español, Madrid, 1989, p. 589. 
hecho es visible en el caso de los protestantes y moriscos. Algunos investigadores han tratado de realizar una aproximación comparativa de ambos casos', demostrando que, si bien guardaron algunas similitudes teológicas, los cristianos nuevos de moros tuvieron el 'privilegio' de ciertas concordias o edictos de gracia que ocasionaron una disminución del número de procesados frente a la otra minoría religiosa.

Éstos fueron diversos y repartidos cronológicamente durante el siglo XVI. En esencia, se trataban de acuerdos entre el Santo Oficio y diferentes comunidades de moriscos en los que se establecía la inmunidad de confiscación de bienes a cambio de cierta cantidad anual de dinero que éstos comprometían pagar al fisco inquisitorial. Tal hecho es fundamental a la hora de cuantificar el número de procesados dentro de cada uno de los grupos heréticos que convivieron en nuestro territorio, ya que los protestantes no gozaron de dicho privilegio, lo cual repercutió en el número de casos conservados.

De todas maneras conviene señalar, para finalizar este breve inciso, que dichos edictos de gracia tuvieron un efecto poco positivo en las tareas evangelizadoras, pues se trataba de un mero intercambio de favores a cambio de unas monedas, no obteniéndose, generalmente, una conversión sincera salvo en contadas excepciones, tal y como nos demuestra el proceso inquisitorial a Hieronimo Montoliu, quien adujo, que tras oír dicha concesión real, decidió abandonar la fe musulmana y abrazar el cristianismo:

«Dixo queste oyo el domingo proximo pasado el hedicto de gracia que su señoria mando publicar en la yglesia de santa Catherina desta villa y aunque es hijo de moros agora quiere ser buen cristiano y bivir como tal y cree todo lo que quiere y cree a la Santa Madre yglesia de Roma" ${ }^{\prime 10}$.

Volviendo al tema del arte y los procesos inquisitoriales, señalar, como anotamos, que uno de los aspectos por los que esta fuente creemos que merece una especial consideración es el de mostrar cuáles fueron las preocupaciones de los procesados y, con ello, del pueblo ante el conflictivo tema de las imágenes. Gran parte de estas dudas estuvieron basadas en el temor hacia el

9. "Finally, the rise of Protestantism in the first half of the sixteenth century also had its averse effect on the Moriscos. Spain viewed Protestantism as the gravest threat to national unity and was committed to eliminate it. As Protestantism spread into southern France and Spain, Spain saw the danger of collusion between Moriscos and Protestants, and set the Inquisition to deal severely with any religious deviation, whether inspired by Muslim traditions or Christians reformers. Though the Moriscos remained faithful to their own traditions, they saw in Protestantism certain elements that conformed with some of their religious thinking -such as the denial of the supremacy of the pope, the frowning on images, and the freedom of the individual to scrutinize the Scriptures. Furthermore, the Moriscos had hoped through their contact with France to shake off the yoke of oppression along with the persecuted Protestant minority". A.G. Chejne, Islam and the West: The Moriscos. A Cultural and Social History, Albany, 1983, p. 9. También Louis CARDAILlac lo hizo en dos estudios: «Morisques et protestants», Al Andalus, 36, 1977, pp. 29-61 y en Moriscos y cristianos: un enfrentamiento polémico: 1492-1640, Madrid, 1979.

10. AHN. Inquisición. Leg. 553. Núm. 10, 1574. 
culto idolátrico de las imágenes, es decir, qué tipo de adoración o respeto se les debía brindar para no caer en pecado. Algunos reos demostraron en sus propias palabras la confusión que les presentaba la veneración de los santos a través de sus distintas representaciones. Por ejemplo, el sevillano, de origen sajón, Gregorio Simón fue procesado por sus declaraciones "especialmente en lo tocante al papa y veneracion de las ymagines y de las obras del purgatorio" ya que "dixo que solo del purgatorio y veneracion de las ymagines estava dudoso" 11 . Obviamente la procedencia del acusado marca un tanto dicha problemática, ya que en su lugar de origen esta diatriba en torno al arte fue piedra de toque en las luchas de religión, pero también podemos encontrarlas en nativos hispanos. Así pues, Santiago Díaz, vecino de Orihuela, fue apresado porque "estando una persona rezando a unas ymagines buelto las espaldas al altar donde estava el Santísimo Sacramento, le dixo por cierto que no querria que estuviesen haciendo oracion a las ymagines porque pareze que es ydolatrar"12.

Este problema nació de la supuesta contradicción entre las leyes bíblicas y la realidad religiosa. La polémica procedía de las palabras del Antiguo Testamento que prohibían la realización de esculturas y su adoración. En dos libros distintos se hacía hincapié en este aspecto: "No te harás esculturas ni imagen alguna de lo que hay en lo alto de los cielos ni de lo que hay abajo sobre la tierra" (Éxodo, 40: 4) y "No os hagáis ningún ídolo ni figura de las que el Señor vuestro Dios os ha prohibido hacer, porque el Señor vuestro Dios es un dios celoso, ¡un fuego que todo lo consume!" (Dt. 4: 19-20). Estas ideas fueron recogidas en uno de los primeros concilios que conservamos, el Ilibertano, celebrado en Elvira (ciudad de la Península Ibérica) entre los años 305 y 311 d. C., cuyo canon 36 fue muy severo en este aspecto. En él "se prohíben las pinturas en la iglesia; que no se pinte en las paredes lo que es objeto de culto y adoración" ${ }^{13}$. En estos tres textos se basaron reformadores como Calvino para defender su aversión hacia el culto que los católicos profesaban, como demuestra en su Institución de la religión cristiana (Christianae Religionis Institutio, 1559), donde se erigió como defensor de la ortodoxia, ante las malas interpretaciones católicas de la tradición.

Podemos creer que estas disputas doctrinales sólo se realizaron en los llamados ámbitos de 'alta cultura' pero no fue así. Muestra de ello serían las interesantes opiniones vertidas ante el tribunal de Zaragoza por un bolsero llamado Bernat de Angay de la zona de Bearne, territorio francés vinculado ampliamente a nivel comercial con el norte de la Península, cuyos habitantes presentaron una mayor aversión hacia las imágenes, tal vez por los propios dictá-

11. AHN. Inquisición. Leg. 2075. Núm. 5, 1574-1577.

12. AHN. Inquisición. Leg. 2022. Núm. 4, 1572.

13. Cfr. R.M. de Hornedo, «Algunas reflexiones histórico-teológicas acerca del culto de las imágenes», en Arte sacro y Concilio Vaticano II, León, 1965, p. 329. También encontramos referencias al mismo en: P.J. GonZÁlez RodríGUEZ, «Los reformadores del siglo XVI y el arte», Goya, 191, 1986, pp. 264-271. 
menes de su príncipe ${ }^{14}$. Es necesario recordar que dicho mandatario se mostró partidario del protestantismo y, al mismo tiempo, fue partícipe de la ayuda a los moriscos en su huida del territorio hispánico ${ }^{15}$. Las palabras del reo recogían esta denuncia a la Iglesia por no seguir sus cánones, por caer en la idolatría; si bien, al final del proceso, tal vez obligado por la propia necesidad de salvar su vida, acabó claudicando, supuestamente, ante los razonamientos que un estudiante le realizó. Este francés en 1586 expresó que "el havia leido en el Apocalipsis que viniendo un angel a hablar a St. Joan le havia querido adorar, y que el angel le havia dicho que no le adorasse sino a solo Dios, y que por alli sacava que no havia de haver ymagines ni Cristos sino solamente adorar a Dios, porque las ymagines eran hechas de hombre [...] dixo que quando Dio le dio la ley a Moyssen para que la diesse al Pueblo havia puesto en ella antes de los diez mandamientos que no adorassemos ydolos ni ymagines sino a solo Dios y el estudiante le respondio que entonces no se podia pintar a Nuestro Señor Jesucristo porque no havia venido al mundo, pero que después que vino y padecio se podia pintar su ymagen y la haviamos de adorar y el reo respondio que con lo que el estudiante le dezia se la havian quitado la duda en aquello"16.

Es muy importante este cruce de opiniones. En primer lugar tendríamos la postura protestante-calvinista de basarse en las Sagradas Escrituras para defender cómo en ellas es criticada la adoración a los ídolos. Y, por otra, la del catolicismo que defendió que tras la encarnación del Salvador, como se hizo hombre, dicha prohibición dejó de ser efectiva, basándose, por ejemplo, en la leyenda del rey Abgar de Odessa, quien recibió unas telas con el rostro impreso de Cristo o, por último, cómo el propio Salvador plasmó su rostro en el manto de la Verónica ${ }^{17}$.

Aun así, el lema común en protestantes y musulmanes es que los dioses no pueden ser representados por objetos sin vida, de piedra o de madera, ni fabricados por la mano del hombre; y mucho menos pueden estar presentes en ellos y ser adorados. Por esto, gran parte de los procesados defendieron por qué nunca se arrodillarían ante una cruz o una imagen ya que no son más que pedazos de madera, yeso o papel. Dichos comentarios se repiten en más de un

14. En el proceso llevado a cabo en 1583 contra Antonio de la Chiessa, natural de Sant Marcelín en Francia, el acusado hace una referencia exacta a esta figura, junto al monarca galo, como instigador de "muchas proposiciones contra el poder del Papa y veneración de las ymagenes". AHN. Inquisición. Lib. 989, 1582-1596, s. p.

15. Véase: Francisco MÁRQuez VIllanueVA, El problema morisco (desde otras laderas), Madrid, 1991 p. 157. También Cardaillac se refiere a esta ayuda demandada por los moriscos valencianos al principado francés a cambio de servirle en «Morisques et protestants...», 1977, pp. 43-45. Más referencias al respecto las encontramos en Antonio DOMínGUEZ ORTIZ y Bernard VINCENT, Historia de los moriscos. Vida y tragedia de una minoría, Madrid, 1978.

16. AHN. Inquisición. Lib. 989, 1582-1596.

17. Pereda hace un recorrido a todas estas leyendas empleadas en la defensa de las imágenes en Felipe Pereda, Las imágenes de la discordia. Política y poética de la imagen sagrada en la España del 400, Madrid, 2007, p. 125 y ss. 
centenar de procesos de toda la geografía hispánica y siempre en términos similares. Por citar algunos ejemplos, Bernabé de Rocaiça, morisco del Reino de Granada, esclavo, insistía una y otra vez que reverenciando a la cruz se adoraba un palo ${ }^{18}$, hecho extensible no solo a esta iconografía sino también a otras imágenes, como la de la Virgen, como podemos comprobar en las palabras del reo de Alcubilla, Esteban Velastre, que "queriendo llevar esta persona una nobena por una imagen de Nuestra Señora dixo que [...] quitad que no es sino un palo que a la del cielo avian de alumbrar y no por aquella que era un palo"19. Incluso se llega a comparar la representación mariana con una albarda, pieza principal del aparejo de las caballerías de carga, que se compone de dos mitades a manera de almohadas rellenas, generalmente de paja, como sucede en la crítica de Isabel Fernández al culto prestado hacia la Madre de Dios ${ }^{20}$.

Estas afirmaciones se repitieron también con las figuras de los santos, como muestra el caso de Matheo Carreras, natural de Bearne, quien expuso que "las ymagines de los sanctos que estan en la iglesia no son sino palos" 21 . Y se hicieron extensibles incluso a todos los materiales posibles empleados en las realizaciones artísticas. El morisco Mordalet de Massalavés criticó, por ejemplo, las representaciones en yeso ${ }^{22}$; o Martín Ruiz, vecino de Martos, ventero de Guadalvacar, hizo mención a los lienzos, aludiendo, esta vez, a la Verónica ${ }^{23}$.

El problema que se les presentaba a los fieles del siglo XVI era no saber hasta qué punto se debía rendir culto a un ser inanimado cuando el hombre, como producción divina realizada a su imagen y semejanza, era una representación más tangible del poder de Dios. Esta reflexión la podemos encontrar claramente expuesta en el proceso a Catalina la Granera, murciana y labradora ${ }^{24}$.

18. AHN. Inquisición. Leg. 4972. Núm. 1, 1574.

19. AHN. Inquisición. Leg. 2022. Núm. 7, 1573.

20. “Ysabel Fernandez, morisca, [...] que pasando un jueves santo la ymagen de Nuestra Señora y los disciplinantes del rosario y diciéndole el testigo que hincase de rodillas que pasava la madre de Dios, havia dicho: calla bestia que no es ymagen de Nuestra Señora sino albarda". AHN. Inquisición. Leg. 1953. Núm. 11, 1578. Transcrito, también, en José María GARCía FuENTES, La Inquisición en Granada en el siglo XVI, Granada, 1981, p. 207.

21. AHN. Inquisición. Lib. 988, 1540-1581, s. p.

22. "Los cristianos se arrodillan delante de un madero que dizen crucifixo, y de una figura de yesso, para que es bueno el madero sino para derles en la cabeça?", AHN. Inquisición. Leg. 806 Núm. 2, 1606.

23. "Martin Ruiz de Martos [...] fue testificado por tres testigos de que viniendo de ciertas mujeres de Jaen en Romeria de ver la santa Verónica y tratando de ellas avian dicho este reo que estan borrachas y que no se a que parten de sus casas tantas leguas por ver un poco de lienço que esta alli, ni se a que van a ber una ymagen que esta figurada un troço de trapo, y que diciendole ciertas personas que avia sido mal, turno a dezir, digo verdad que desas ymagines yo tengo alli una, y en sus casa las tienen. El qual siendo llamado estuvo siempre negativo hasta que le fue puesta la acusacion que declaro ser verdad lo que los testigos decian aunque no avia sido su intencion dezir mal de la veneracion de las ymagines y por ser hombre muy fermo fue penitenciado", AHN. Inquisición. Leg. 2075. Núm. 5, 1574-1577.

24. AHN. Inquisición. Leg. 2022. Núm. 25. 1595-1596. 
Dicha rea fue testificada porque, arrodillada en la misa mayor cuestionó si era mejor adorar a un hombre o a una imagen. Catalina explicó que creía que mejor sería rendirle culto al primero de ellos, ya que el Cristo que tenía delante era hecho "de un palo con berniz" mientras que el hombre "era criado a la ymagen y semejanza de Dios". Los testigos le explicaron que no todos los hombres son buenos ya que éstos podían "estar excomulgados y con pecados". La rea siguió insistiendo, aun afirmando que sabía que sus proposiciones estaban relacionadas con aquellas herejías que "quitan la adoración de las ymagines". Tanto es así, que seis meses más tarde fue de nuevo denunciada porque "al alçar a Nuestro Señor y habiéndose yncado de rodillas y reçado miro a uno de ellos y dixo: bendito y adorado seys vos mi señor Jesucristo bien dicen que no ay mas linda ymagen ni mas perfecta, que es la del hombre que la hizo Dios a su ymagen y semejanza con su mano y misericordia y desto avia respondido uno: linda es la de un Cristo y ella replico, linda es pero pintala un hombre, y diciendole que el hombre tenia pecados ella replico: no miro yo sus pecados del hombre sino que lo hiço Dios de su bendita mano a su ymagen y semejanza" ${ }^{25}$. Es decir, la rea tergiversó las enseñanzas que le dieron, al entender que también el artista puede ser pecador como la imagen humana que ella quería reverenciar. Así, pues, este proceso nos demuestra las preocupaciones habituales que podía tener un fiel del siglo XVI, esto es, no entender la materialidad de lo divino y confundir la información que le era explicada. También resulta patente cómo estaban al tanto de las posibles herejías en las que podían incurrir en relación a las imágenes, hecho que ratifica cómo no fue un problema teológico cercano a las altas esferas eclesiásticas, sino que tuvo una gran difusión entre el vulgo. Podemos también extraer otra conclusión: que la representación artística de Cristo se justificó por el hecho de que Dios se había hecho hombre, pero ello no implicaba, al menos para dicha rea, que a éste se debiera adorar.

Pero no fue el presentado un caso aislado. También en otras diócesis, como la de Granada, se pueden encontrar testimonios similares. Nos referimos al proceso contra Lope Díaz, que mirando a un crucifijo dijo que "quando Sant Joan Baptista estava en el desierto no hazia penitencia sino que mirava a Jesucristo de cara a cara y que era mas adorar a un hombre que Dios avia hecho que a un crucifijo". Recurre al mismo tópico que la rea anteriormente citada diciendo que "el crucifijo le havia hecho un oficial y al hombre le havia hecho Dios y uno de los testigos añade que avia dicho que faltando un Christo se podia adorar un hombre en semejanza de Dios Nuestro Señor" ${ }^{26}$. Es decir, los acusados no sólo se cuestionaron la validez o no de una imagen, sino las razones que llevan a su rechazo. Junto a las críticas protestantes y moriscas de cómo el problema radicaba en la idolatría a un trozo de madera, se pueden unir éstas,

25. Ibídem.

26. AHN. Inquisición. Leg. 1953. Núm. 13, 1580. También transcrito en José María GARCía FuENTES, op. cit., p. 226. 
es decir, la participación humana en la conformación de una representación de la divinidad, un hecho que preocupó tremendamente a los cristianos viejos.

Relacionado con la figura del artista, como mediador o conformador de unos modelos que serían adorados y cuya intercesión producía la invalidez del culto a la imagen, podemos presentar otro caso significativo. Nos referimos al de Pedro Hernandez Perote, natural de Ibiza pero residente en Jaén, que tras criticar el culto que diversas feligresas le rendían a la imagen de Nuestra Señora de Santa María de la Cabeza y repetir que sólo se debía reverenciar el Santísimo Sacramento, afirmó que "Nuestra Señora de la Cabeza era imagen formada de maestro; y que no había otra cosa si no Dios y Santa María"27. Es decir, por un lado podemos ver, una vez más, una crítica a la materialización de la divinidad, fruto de la labor del artista, y por otra una negación consciente de la veneración física de los pilares de la religión cristiana. Crítica que se repitió en otros procesos como en el de Bartolomé Sánchez Velloso, de Alcaudete, en el que el reo incluso comparó lo que permitía la Iglesia con lo que otras religiones, como la de los turcos, llevaban a cabo en sus ceremonias ${ }^{28}$.

Curiosamente esta aversión ante los artistas como mediadores y responsables del culto idolátrico también se puede encontrar de modo concreto en otros procesos inquisitoriales. Por ejemplo en el celebrado en Zaragoza en 1588, Beltrán de Roda, nuevamente originario de Bearne, "tratando de ciertas personas que tenian amistad con otras que heran entalladores y hazian sanctos y los favorecia dixo como burlandose que persona que tenia amistad con aquellas personas que heran guitones y hazian santos que porque los santos no ayudaban" ${ }^{29}$. Es decir, se posiciona no sólo en contra del culto a los santos, sino también a sus imágenes y artífices ${ }^{30}$.

Hasta ahora hemos expuesto tres de las grandes preocupaciones que atormentaban a parte de los feligreses del siglo XVI: el temor a la idolatría y, con

27. AHN. Inquisición. Leg. 1856. Núm. 7, 1571. Transcrito en Rafael Gracia Borx, Autos de Fe y Causas de la Inquisición de Córdoba, Córdoba, 1983, pp. 69-70.

28. “Bartolomé Sánchez Velloso, que ha sido y agora es guarda del campo [...] porque mirando un paño en que estaba pintado un Cristo crucificado, dijo a otra persona: 'creeis vos; en ese no creo, sino en el del cielo, que esas semejanzas y esas de las iglesias qué son, sino ídolos, que estos eran de antes ídolos en que doraban, ándense ahí los pintores haziendo semejanzas [...] y diciendole cual está Dios por el Cristo crucificado que dijo no echando el ver en el papel ese es Dios: no creo en ese, que Dios está en el cielo, que ese es papel que pintó el pintor. Yo creo en Dios y en su Madre y en lo que reza la Santa Madre Iglesia de Roma, que también traen los turcos ídolos en que hacer sus ceremonias, que cuando se perdió Caramami los tornaron unos ídolos que están en Málaga y así me parece ese' y que no estuvo en más de mirar el papel que si entendiera que era imagen de Jesucristo no lo dijera", AHN. Inquisición. Leg. 1856. Núm. 10, 1572. Transcrito también en Rafael GrACiA BoIX, op. cit., 1983, pp. 88-89.

29. AHN. Inquisición. Lib. 989, 1582-1596, s. p.

30. En otros procesos podemos encontrar incluso que los reos afirman que estarían totalmente en contra de ser artistas para no incurrir en estos pecados, así en 1570 Rodrigo de Velasco, de origen portugués, afirmó “si yo fuera carpintero no hiziera aquellos ydolos porque los descreyentes no creyeran”, AHN. Inquisición. Lib. 988, 1540-1581, s. p. 
ello, actuar como los gentiles ${ }^{31}$, actitud que tanto había sido criticada años atrás. En segundo lugar, el valor de la imagen en cuanto 'elemento matérico' que representa a una divinidad y, por último, el papel del artista en todo el proceso, como posible 'corruptor' de la misma pureza de la idea y del sentido de la religión. Toda esta problemática, sobre todo la referida al material con el que se compone la figura, no nació en este siglo, sino que fue producto de un problema latente desde los orígenes de la religión. Como recogió Freedberg ${ }^{32}$, los neoplatónicos del siglo III trataron de justificar cómo no veneraban piedras e imágenes como si fuesen dioses, sino que su plasmación artística venía dada por la necesidad de representar las fuerzas y poderes incorpóreos e inmateriales mediante imágenes que les sirvieran como recordatorio, de modo que quienes vieran tales cosas y las veneraran pudieran llegar a concebirlas.

Esta preocupación siguió latente en el medioevo. Muestra de ello serían las palabras de Santo Tomás de Aquino (1225-1274), quien en su razonamiento sobre qué culto se debía rendir a la imagen aludió a la sustancia material de la misma, a la necesidad de ella para visualizar la idea, insistiendo, una vez más, que no se debía venerar el producto manufacturado sino a su representación ${ }^{33}$.

En el mundo moderno fue Paleotti (1522-1597) uno de los que mejor expuso esta idea. Nos habló de una triple consideración de la imagen, de cómo confluyen tres factores en ella: el material, la mano de obra del artista que lo modela y, por último, el mensaje, que es lo más importante, aquello que debe venerarse o adorarse según merezca un tratamiento de dulía, hiperdulía o latría. El cardenal italiano expuso:

"Intorno a che, lasciando le questioni scolastiche da parte, diciamo che nelle imagini si possono considerare tre cose: l'una è la materia della quale elle son fatte, come sa-

31. Son varios los procesos en los que se emplea dicha terminología para criticar el culto a la imagen, emparentándolo con los gentiles. García Arenal, en su estudio del tribunal de Cuenca, cita el caso del reo que afirmó que "las ymagenes que adoravan los christianos son dioses de madera como los que antiguamente tenian de yeso los gentiles" (Mercedes GARCíA-ARENAL, Inquisición y moriscos. Los procesos del Tribunal de Cuenca, Madrid, 1978, p. 105). Hecho que se repite también, por aportar otro ejemplo, en Valencia, donde un acusado de luterano afirmó que "queriendo quitar y negando la veneración y reverencia que se debe a las imagines de los sanctos, aprobando la secta luterana aduciendo que las imagines de los sanctos son ydolos y que no se an de adornar, lo qual todo creyo por spacio de un año", AHN. Inquisición. Leg. 531. Núm. 31, 1568.

32. David FreEDBERG, El poder de las imágenes, Madrid, 1992 [1989], p. 224.

33. “Acerca de la veneración de las imágenes, es decir las imágenes de Cristo, la cruz, y las de los santos, pueden ser consideradas de dos formas diferentes. En un modo, en tanto que son imágenes de dios, de la Virgen María y de los Santos que representan a Dios, la Virgen María o algún otro santo. En segundo lugar, en tanto que son cierta cosa, como oro, plata, madera o piedra. $\mathrm{Y}$ en este segundo modo no debe manifestarse veneración ninguna, porque en tanto que cosas solamente, se veneran como tales. Otro modo de considerarlas es en tanto que representan a Jesu Cristo o la Virgen María o a los santos del paraíso y así la cruz de Cristo y su imagen debe ser venerada con adoración de latria, mientras que la imagen de la Virgen María y de los restantes santos debe ser de dulia, porque todo honor se refiere al prototipo, esto es, a la [imagen] ejemplar o imaginativa". Cfr. Felipe PeredA, op. cit., pp. 119-120. 
rebbe a dire l'oro, l'argento, l'avorio e cose tali, la seconda è la forma data dall'autori e tal materia con disegni, lineamenti et ombre, etc. la terza è ciò che risulta dalla materia e figura insieme, ch'è quella cosa che chiamiamo imagine, rappresentante un'altra cosa, della quale essa è similitudine. E di qui nasce che nel mirarla possono cadere in noi varii pensieri: l'uno dirizzato alla materia, come pregiata, ricca e vaga di colori, l'altro, come a cosa disegnata con grande artificio, e con molta diligenza figurata, il terzo, come ad imagine, cioè in quanto fa lo affetto di rappresentare un'altra cosa, nel qual modo non attendiamo più all'opera come materia o figura ma alla cosa rappresentata, che è in lei per modo di rappresentazione et in questa fissiamo il pensier nostro. Nei primi due modi non diamo noi sorte alcuna d'onore o riverenza a questa opera, se bene sia d'oro o di perle [...] nel terzo modo prendiamo noi esse imagini non come semplici figure, ma sotto questo atto di rappresentare il che vuol dire che, riguardando noi con gli occhi corporali nella imagine, la mente si fissa nella cosa rappresentata e contenuta in essa per modo di rappresentazione, e di qui nasce che quell'onore che si conviene alla cosa rappresentata si potrà ancora misteriosamente attribuire alla imagine, secondo i gradi di latria, iperdulia e dulia, di sopra da noi dichiarati [...] Quando si adora Cristo senza imagine, l'adoriamo secondo il suo proprio modo di essere, e quando l'adoriamo nella imagine, l'adoriamo nell'essere rappresentativo et imaginato" 34 .

Podemos ver recogidas y expuestas en el texto de Paleotti las tres preocupaciones que hemos extractado de los procesos inquisitoriales, que no hacen más que acercarnos a la realidad cotidiana del momento y justificar por qué eran necesarios estos tratados artísticos o teológicos que explicaran al fiel aquellos aspectos más incomprensibles de su religión y validaran, de un modo más concreto al que lo hiciera el gran evento ecuménico de Trento, las normativas referidas a las representaciones pictóricas y escultóricas del hecho divino.

Gran parte de esta confusión nació de las obligaciones por parte del poder político y religioso de imponer el culto a la imagen como síntoma de cristianización. Ya vimos cómo se obligó a todo habitante en territorio peninsular a poseer imágenes en sus moradas para demostrar la pureza religiosa y su adhesión a la Iglesia. Ignacio de las $\operatorname{Casas}^{35}$, Jerónimo Corella en sus Advertimientos sobre la conversión de los moriscos de Valencia $^{36}$, o el doctor Carvajal ${ }^{37}$ junto

34. Gabriele PAleotti, «Discorso intorno alle imagini sacre e profane», en Paola BAROcCHI (ed.), Trattati d'arte del Cinquecento. Fra Manierismo e Controriforma, Bari, 1961 [1582], pp. 253-254.

35. “Y quando estuvieren enfermos [los moriscos], tengan allí cruz e imágenes, también en salud las tengan en su casa y en los aposentos donde ellos y sus hijos duermen", B.L. Mn. Add. 10238, Ignacio de las CASAS, De los moriscos de España (1605-1607), fol. 11.

36. “Y para que todo se execute bien, será necesario que después de la predicación se señale bastante número de visitadores, los quales muy a menudo den buelta por los lugares de los Moriscos [...] y que con amor vean sus cosas y les acostumbren a poner imágines en ellas y les den algunas limosnas, y los junten a menudo en las iglesias para enseñarles los misterios de nuestra sancta fee", BNM. Mss. 11262/11. Jerónimo CoRELLA, Advertimientos sobre la conversión de los moriscos de Valencia, 1542.

37. Lo expuso en un memorial enviado al rey: “En lugar de estos objetos, es menester que los moriscos lleven la cruz y a Nuestra Señora [...] porque las personas y las cosas se conoçen por 
con los ya citados Figueroa o Hernando de Talavera defendieron esta idea, pues rendirles culto, o al menos poseerlas, creían que era síntoma de cristianización y de haber dejado atrás sus creencias musulmanas. De hecho, este asunto no es novedoso, ya que, como expuso Pereda, los judíos en el medioevo compraban imágenes con el fin de evitar ser condenados inquisitorialmente ${ }^{38}$.

Al menos a día de hoy, que les rindieran culto es un hecho que no podemos certificar. Que antes de las campañas evangelizadoras no las conservaban en sus casas sí que es un hecho fehaciente, tal y como encontramos en las denuncias del obispo Salvatierra de Segorbe, que expuso cómo sus hogares estaban limpios de cualquier imagen ${ }^{39}$. Partiendo de esta inexistencia, sí que podemos aportar otros casos que certifiquen que, poco a poco, esta sociedad marcadamente iconófoba, comenzó a sentir cierto apego hacia las imágenes. Recordemos el caso del retablo de San Miguel que produjo, en Valencia, diversas conversiones dentro de una mezquita ${ }^{40}$, o cómo los musulmanes pidieron piezas metálicas para llevar sobre sí y rendirles culto ${ }^{41}$. A todo ello deberíamos añadir cómo en otras zonas, véase Sevilla, conservamos testimonios de la devoción que profesaban hacia las mismas, cómo poseían rosarios, entregados éstos en las campañas evangelizadoras, o representaciones de Cristo crucificado, iconografía habitual en los procesos de conversión llevados a cabo en el sureste peninsular. Este dato fue aportado por Perceval en su estudio de los cancioneros de la zona.

las señales que tienen y se juzgan ser de aquel cuyas señales traen”. Cfr. Augustin REDONDO, «El primer plan sistemático de asimilación de los moriscos granadinos: El del doctor Carvajal», en Les Morisques et leur temps, París, 1983, p. 115.

38. “Lo que sí sabemos con toda seguridad es que comprar imágenes es lo que hicieron multitud de conversos [judíos] desde el momento en que el Santo Oficio empezó su cizaña por las ciudades de Castilla", Felipe PeredA, op. cit., p. 53.

39. "Item, es notorio en toda España que ningun lugar de moriscos a hecho hermita ni cruz ni humilladero alguno en sus pueblos y lugares donde moran, y es notorio el aborrecimiento que tienen con las figuras e imágenes pues no se hallara haver echo alguna en las iglesias ni tenerlas en sus casas, y lo mesmo se dice del agua bendita, y de las cofradías, y de las indulgencias y bulas de la cruzada, y religión, frailes ni monjas, pues es cosa sin duda que no se hallara morisco alguno hombre ni muger que goce de ninguna de las dichas devociones ni aya sido ni era confrade del Santisimo Sacramento ni de la sangre de xpo ni de otra ninguna cofradía de sanctos ni aya tomado ni tome bula de la cruzada", Mercedes GarcíA-Arenal, Los moriscos, Madrid, 1975, p. 162.

40. Escolano nos cuenta que el día de San Dionisio un retablo dedicado a la figura de San Miguel fue tomado por unos niños, de modo milagroso, y llevado hasta la mezquita musulmana de esta ciudad donde oraban los moriscos, quienes al ver tal acto se pusieron a alabar dicha figura, dejándola en la capilla del Alfaquí y ocasionando una conversión en masa. Vid. Gaspar EscolANO, Décadas de la Insigne y Coronada Ciudad y Reino de Valencia, Valencia, 1610, pp. 924-925.

41. En las epístolas jesuíticas podemos encontrar: "Admiten éstos [refiriéndose a los moriscos] y aun ruegan, los demos imágenes de algún metal para llevarlas colgadas al cuello, reverenciarlas y besarlas acordándose de lo que representan. Lo qual, hasta agora, ha sido muy ageno dellos. Afficionándose a leer algimia y nos ruegan se la enseñemos con la doctrina christiana", «Información de algunas cosas que se me ofrecen acerca delos Christianos nuevos deste Reyno de Valencia delo que toca a su conversión después de aver vivido entre ellos y tratadolos algun tiempo", en ARSI. Epist. Hisp. 127. Epistolae Hispaniae. 1579. 
Tal vez, al basarse en textos sobre la expulsión, esta muestra de religiosidad externa fuera debida a un intento por parte de los moriscos de evitar lo inevitable, esto es, que fueran deportados de territorio hispánico o, en el peor de los casos, ajusticiados y condenados a muerte ${ }^{42}$. De todas maneras, podemos presentarlo como un ejemplo de cómo gracias a la labor ejercida por la Iglesia -que no por los nobles-, con el fin de aculturar y socializar a dicho colectivo, las imágenes acabaron teniendo un papel importante en la vida de los nuevamente convertidos, bien como un elemento más de su "disimulo" o como epicentro de su ira iconoclasta ante la imposición de culto, hecho que analizaremos más adelante.

Tal vez, partiendo de este renacido interés del musulmán por la imagen y el recelo del cristiano viejo ante él, podemos analizar unos procesos inquisitoriales muy curiosos donde se acusa a unos moriscos de rendir culto a una escultura de Mahoma. Éstos han permanecido inéditos hasta hace bien poco y son realmente interesantes ${ }^{43}$. El primer ejemplo data de mediados del siglo XVI, cuando fue apresada la valenciana Catalina Martínez Buxá por poseer "un bulto vestido de colorado y que era la figura de Mahoma" ${ }^{44}$. Este hecho se repite un cuarto de siglo más tarde, cuando en 1588 el reo Jerónimo Anjab fue llevado ante el Santo Oficio aragonés por "haver visto en casa deste morisco del mesmo lugar que sacaron de una arca un bulto de plata, de gordor de un braço y de alçar de un palmo y les oyo dezir aquel bulto hera la figura e ymagen de Mahoma y poniendolo sobre una mesa arrodillados lo adoraban" ${ }^{45}$. Finalmente, en 1592, Isabel Obres fue condenada en este mismo tribunal por "adoración de la estatua de Mahoma" ${ }^{46}$. Estas denuncias se convierten en más inverosímiles si atendemos a la procedencia geográfica de los acusados y sus tribunales: las diócesis de Zaragoza y Valencia, que aglutinaban la población más islamizada de la Península, por lo que era impensable que esto se diera teniendo en cuenta la naturaleza de los moriscos que allí residían, representación de la ortodoxia militante más acusada. Estos ejemplos nos sirven para ver

42. “Otros llamaban a voces / a la Virgen del Rosario/ Y a la virgen de Belén: / Ella sea en nuestro amparo. / Tanto es su sentimiento/ que a los niños en los brazos/ que criaban a sus pechos/ por leche les daban llanto./ La insignias que llevaban/ gran devoción provocando,/ todas mantelinas blancas. / Compuestas a lo cristiano. / Cada cual lleva sus cuentas, / que son devotos rosarios; / Va con ellos un pendón/ dibujado y esmaltado/ un devotísimo Cristo,/ adonde van contemplando; / Y muchos de los moriscos, / antes de ser embarcados, / dejaron muy ricas mandas / a los templos señalados. / Hubo entre ellos mercader/ que en San Julián es nombrado, / que a la Virgen de la Iniestra/ Dejó cuatro mil ducados./ Otros dejan paramisas, / otros hacen cabo de año". Cfr. José María Perceval, Todos son uno. Arquetipos, xenofobia y racismo. La imagen del morisco en la Monarquía española durante los siglos XVI y XVII, Almería, 1997, p. 116.

43. Estos textos los publicamos por primera vez en un artículo dentro del número monográfico dedicado a los moriscos de la revista Manuscrits. El título de nuestro trabajo es: «Los moriscos y la Inquisición. Cuestiones artísticas», Manuscrits, 28, 2010, pp. 87-101.

44. AHN. Inquisición. Lib. 936, 1550-1580, s. p.

45. AHN. Inquisición. Lib. 989, 1582-1596, s. p.

46. AHN. Inquisición. Lib. 989, 1582-1596, s. p. 
cómo los cristianos viejos acusaron a los moriscos con argumentos falsos, sin conocer su teología. Creían que, al igual que ellos, los musulmanes podían ser idólatras y los atacaron en este clima de crispación. Visto cuatro siglos después entendemos cuánto odio pueden ocultar dichas acusaciones, aunque no por ello podemos plantearnos si realmente hubo una transposición de culto y una ósmosis religiosa entre ambas costumbres, hecho que consideramos que debe ser estudiado de modo monográfico y que ocupará próximas investigaciones.

La actitud de los habitantes de nuestro territorio ante estos problemas teológicos no fue siempre la reflexión pacífica y el acatamiento de la legislación católica, sino que se puede englobar en tres grandes grupos: aquellos cuya reacción fue simplemente la de no adorar a las imágenes y, por ello, fueron procesados. El segundo, que englobaría a los que se burlaron públicamente de ellas y, por último, los más radicales que se encargaron de destruirlas como síntoma de su rebeldía.

La primera de las tres actitudes fue la menos visible pero la más abundante de todas. Podría darse en dos situaciones: no haber mostrado reverencia a la imagen en un pasado o, por el contrario, no querer inclinarse ante ella en el propio proceso inquisitorial. Estos ejemplos se repiten en toda nuestra geografía y no podemos relacionarlos únicamente con la presencia de protestantes y moriscos sino también con casos de cristianos viejos que renegaron del culto supuestamente idolátrico. Tal sería el caso del prior de la iglesia de San Pedro de Úbeda que fue procesado por prohibir que se realizaran misas en la capilla del Crucifijo de la iglesia, aduciendo falsamente que la propia Inquisición lo había solicitado porque no se debía adorar ya que era de palo ${ }^{47}$. O también de un cristiano viejo valenciano llamado Miguel Centellas, que al entrar en la iglesia de San Jorge "se puso a mirar unas pinturas de una acostamiento de Nuestro Señor Jesucristo donde ny se arrodillo ni rezo [...] y el dicho don Miguel viendo que tardaban en fazer oracion les dijo se levantasen porque no se debia fazer oracion a los santos y que no se hallava sino un solo Dios" ${ }^{\prime 4}$.

Esta postura herética de falta de respeto ante la representación pictórica enlazaría con la que tuvieran los propios moriscos, cuyo ejemplo podría ser el del procesado García, vecino de Motilla, que fue apresado porque "passando muchas vezes delante una cruz sin hacerle reberencia le dixeron que porque no se quitaba la caperuça a la cruz, respondió a quien tengo de quitar la caperuza, a aquellas piedras que estan alli, no quiso quitarle y diciendole no vees que aquella cruz de piedra es remembranza de la pasión de Jesucristo crucificado, respondió y no quiero quitar la caperuça a la cruz porque mis padres me lo confesaron" ${ }^{\prime 9}$. O por la facción protestante, que podemos ver en la acti-

\footnotetext{
47. AHN. Inquisición. Leg. 497. Núm. 2, 1570.

48. AHN. Inquisición. Leg. 530. Núm. 9, 1567-1570.

49. AHN. Inquisición. Leg. 4972. Núm. 1, 1574.
} 
tud de Pedro de Gales, de Ulldecona pero que había vivido la mayor parte de su vida en Orange, "que en presencia de los dichos testigos havia negado la auctoridad y postestad del Sumo Pontifice y el valor de la misa y el usso de las ymagenes y quando passava por este Reyno encontrando algunas ymagenes ocurre no les hazia reverencia [...] hallaron ciertos papeles en ellos muchas proposiciones hereticas y algunos versos en oprobio de la reverencia y adoración de las ymagenes e intercesión de los sanctos [...] y en consecuencia de esto nego la adoración de las ymagenes [...] no se havia quitado en España el sombrero a ymagines y cruzes ni haver hecho reverencia" ${ }^{\prime 50}$.

Esta fue una constante repetida en numerosos procesos inquisitoriales y explica cuán importante era el arte dentro de la mentalidad religiosa moderna como signo visible de la religiosidad y representación de la divinidad. El hecho de no rendir veneración ante una imagen era suficiente para ser apresado y condenado, demostrándose que no es un factor que podamos sólo relacionar con las minorías religiosas disidentes sino también, como vimos, con los propios cristianos viejos. Nadie estaba a salvo del control inquisitorial y cualquier actitud medianamente ortodoxa era severamente juzgada, no en vano, el arte era la máxima representación visual de una religión acosada por diversas herejías que hacían tambalear su primacía.

Como hemos dicho, otras veces el arte fue utilizado dentro del mismo proceso inquisitorial al ser mostrado al reo para conocer sus tendencias religiosas. Así ocurrió en la acusación a Antonio de Cipari, siciliano vecino de Sevilla que tras ser arrestado por romper un rosario "dandole adorar un Christo crucificado no lo quiso adorar antes se tapava los ojos por no verlo" ${ }^{51}$. O en el de Gabriel Royo, de origen morisco, que en la propia cárcel donde se desarrollaba el juicio fue obligado a adorar un crucifijo "y no le asiendo acatamiento le dixeron que se rudillase y el se rudillo y luego se levanto y dixo que no avia visto al asno entendiose que lo avia dixo por el crucifixo" ${ }^{\prime 52}$. Hecho que se repitió con Juan de Casanova a quien en Zaragoza, en 1591, "mostrandole una cruz y una ymagen de Nuestra Señora diciéndole que las adorase no quiso y se tapo la boca con las manos y volvia la cara por no adorarlas" ${ }^{\prime 53}$. Con estos ejemplos seleccionados,

50. AHN. Inquisición. Lib. 989. 1582-1596, s. p. Este proceso ha sido estudiado con detenimiento en Doris MOREno y Antonio FERnÁndeZ LuZÓn, Protestantes, visionarios, profetas y místicos, Barcelona, 2005. Relacionado con este hecho podemos encontrar otros casos en los que incluso se habla de calvinismo y luteranismo por no reverenciar una imagen. Un ejemplo de ellos sería el juicio de Joquem Orinar, marinero de un navío alemán que "fue testificado por ocho testigos de que estando en la Villa de Rota no quiso adorar ciertas ymagines ni mirar ni besar una cruz que se le ponia delante diziendo que el cielo y el que en el estava que era dios se avia de adorar y preguntandole si era calvinista dixo mucho mal de calvino y se declaro que era luterano", AHN. Inquisición. Leg. 2075. Núm. 9, 1592.

51. Ibídem.

52. AHN. Inquisición. Lib. 989, 1582-1596, s. p.

53. Ibídem. 
entre los muchos encontrados, se constata el citado valor del arte como elemento de examen y, por otra parte, el grado de insurrección por parte de los procesados que, aun a sabiendas que su vida pendía de un hilo, prefirieron seguir fieles a sus doctrinas delante del propio tribunal como muestra de su beligerancia ante el momento represivo en el que vivían, en defensa de su propia religión ante el constante asedio católico en búsqueda de la unidad de la fe.

El segundo grupo, que engloba las actitudes de burla y escarnio ante las representaciones artísticas de tema religioso, recogería afrentas verbales más o menos extremas que podían expresarse mediante una larga explicación del suceso o simples palabras que hicieran referencia a la actitud del reo ante ellas. Así sucedió, por ejemplo, en el caso de Agueda Bernardino, morisca de Alhama la Seca de tan sólo 13 años de edad que "fue presa por aver burlado de unas ymagines del descendimiento de la cruz y dicho otras cosas de la secta de Mahoma" ${ }^{54}$. De todas maneras, era más habitual que se indicara cuáles fueron las palabras exactas expresadas por el acusado vilipendiando la imagen. Estas fueron de lo más variopintas, moriscos que tildaron representaciones marianas de "goleta" 55 o "moça de cantaro" 56 ; otros que vieron en las cruces representaciones de diablos 57 , o las tacharon de "espantajos" y "palos llenos de hormigas" $^{\prime 58}$ o también de "perros colgados" $" 59$. Incluso el escarnio pudo suponer situarla de modo invertido en sus aposentos, cumpliendo así los preceptos de poseer imágenes en casa pero haciéndolo de modo insurrecto y ofensivo ${ }^{60}$.

54. AHN. Inquisición. Leg. 4972. Núm. 2, 1578.

55. "Miguel Aquen alias Azizo, morisco [...] mirando a una ymagen de Nuestra Señora que estava colgada de una pared dixo con menos precio y mofandose della, mira qual esta la goleta", AHN. Inquisición. Lib. 988, 1540-1581, s. p.

56. “Andres Franco [...] que viendo una imagen de Nuestra Señora mal pintada avia dicho que parecia moça de cantaro", AHN. Inquisición. Leg. 1953. Núm. 2, 1563.

57. "Uno de ellos pregunto al testigo que quando hicieron en nuestra la procesion para sanct Urbe quantas cruzes avia, y el testigo dixo que mas de sesenta, y el reo con los demas respondieron, sesenta diablos que los llevaran al infierno", AHN. Inquisición. Lib. 989, 15821596, s. p.

58. "Miguel Xarquin, morisco, [...] y cayendo otra vez se encomendo a Mahoma y por un crucifixo que estava pintado en una pared dixo, 'quita, quita que son espantajos' y se avia reydo de ciertos cristianos porque quitavan las caperuças a una cruz y dixo: putos cristianos quitares las caperuças a un palo atravesado lleno de hormigas", AHN. Inquisición. Leg. 1953. Núm. 5, 1571. También citado en José María GARCía FuENTES, op. cit., pp. 102-103.

59. “Garcia de Çafra, morisco [...] que los crucifixos que estavan en las iglesias parecian perros colgados", AHN. Inquisición. Leg. 1953. Núm. 7, 1574. También citado en José María GARCíA FUENTES, op. cit., p. 125.

60. "Entraron en una casa de un morisco que se llama Miguel Mascon y en una paret vieron que estaba un papel pegado con pasta, y en el lado mas real un cruscifixo labrado y los pies arriba y por ser la casa de moriscos y es publica voz y ama viben como moros. Les abia dado sospecha que por irrisión abian puesto de aquella manera el cruscifixo y tambien por la muger de la dicha casa se abia turbado que le abia dicho que estaba asin aquella figura", AHN. Inquisición. Leg. 806. Núm. 5, 1580. 
Tampoco los santos se libraron de recibir estos vituperios, no en vano fueron definidos como "vestiazas" ${ }^{61}$ entre otros calificativos. Esta actitud procedía de la visión irónica que moriscos y protestantes tenían de la teología de la imagen católica, emparentando cada representación artística con un término vulgar que intentara hacer ver a sus coetáneos que estaban equivocados y cuán ridículo era venerar trozos de madera. De todas maneras, esta actitud podemos tildarla de pacífica, si la comparamos con los actos iconoclastas realizados por estos mismos en dicho periodo.

La mayor parte de atentados físicos contra la imagen podríamos justificarlos como un imperativo nacido de la propia tradición religiosa de su colectivo. Bien sabido es cómo calvinistas y protestantes, en sus países de origen, llevaron a cabo una serie de revueltas, no siempre aceptadas por sus líderes religiosos $^{62}$, con el fin de buscar la pureza en el culto religioso. Investigadores como Christin compararon la actitud de los protestantes franceses -con sus actos destructivos ante la decoración de las iglesias-, con la que realizara el Salvador cuando irrumpió en el templo de Salomón y desalojó a los comerciantes que allí desarrollaban su labor ${ }^{63}$.

Por otro lado, los moriscos se basaron en la tradición que narra cómo Mahoma llegó a la Ka'ba y se encontró con que en el santuario había pinturas de ángeles, profetas, árboles... y viéndolo mandó destruir todas aquellas imágenes que habían sido depositadas por los peregrinos ${ }^{64}$ porque no eran lícitas éstas, ya que estaba totalmente en contra de la representación figurada de la divinidad, ente que debería ser inaprensible a nuestros ojos. Esta actitud beligerante fue asimilada y repetida por gran parte del mundo musulmán.

61. "Juan de Caso, natural de Aresi en Bearne [...] pasando por la casa de un pintor en cuya puerta estava una ymagen o testa de bulto de sant Martin la estuvo mirando el reo muy grande rato y se fue y entre medio quitaron de alli la ymagen y volviendo el reo por alli pregunto al pintor que alli estava que havia hecho aquella vestiaza que tenia antes a la puerta y respondiendole que vestiaza dixo aquel que estava con aquella coraça y entendiendo que le dezia por la testa de Sant Martin”, AHN. Inquisición. Lib. 989, 1582-1596, s. p.

62. Lutero fue defensor de las imágenes, no en vano, en relación a los actos iconoclastas perpetrados por sus coetáneos expuso que: “Dios ha querido que sean libres los hombres [...] porque uno ha destruido y quemado las imágenes (y destrozado el crucifijo), ¿todos tenemos que quemarlas? No tanto, queridos hermanos... Nosotros podemos hacer imágenes y retenerlas mas no adorarlas. Y, si alguien las adora, entonces sí podemos destruirlas y abolirlas... mas no es forma tumultuosa y violenta, sino por orden de la autoridad". Cfr. P.J. GoNZÁlEZ RODRÍGUEZ, op. cit., p. 266.

63. O. CHRISTIN, Une révolution symbolique. L'iconoclasme et la reconstruction catholique, París, 1991, p. 128.

64. Para un estudio detallado de la actitud islámica ante la imagen véase: Jean François CLEMENT y Gilbert BAUGE, L'image dans le monde arabe, París, 1995. Oleg GRABAR, «Islam and Iconoclasm», en A. BREYER y J. HERRIN (eds.), Iconoclasm. Papers given at the Ninth Spring Symposium of Byzantine Studies, Birmingham, 1977, pp. 45-52. Del mismo autor: «Actitudes islámicas ante las artes», en La formación del arte islámico, Madrid, 1984, p. 31 y ss. 
Ya en nuestra tesis doctoral abordamos diversos aspectos relativos a la iconoclastia morisca comparándola con la protestante en el ámbito valenciano ${ }^{65}$. En este caso, nuestra intención se centrará en englobar todos estos sucesos emparentándolos con el resto del territorio hispano intentando establecer unas directrices generales para su análisis.

La cruz, como elemento representativo de la religión cristiana y complemento visual de las prédicas ${ }^{66}$, fue una de las representaciones que más sufrió en nuestra geografía por estos ataques individuales o colectivos hacia el sometimiento religioso. Tanto moriscos como protestantes se ensañaron en su destrucción en lugares públicos y privados. Tal vez los más representativos fueran los primeros, destacando las acciones llevadas a cabo contra las cruces de término situadas a las afueras de la ciudad. Pedro López, vecino de Chinchilla, fue ajusticiado porque "avia quebrado y derribado a pedradas una cruz que estava en un camino de viaje una legua de la ciudad" que según testigos "avian visto el dia antes la cruz sana y buena y que ahora tenia señales de pedradas" ${ }^{\prime 67}$. Acción repetida en Valencia por Joan Borrido en $1573^{68}$ o por Diego Gosqui en Zaragoza seis años más tarde ${ }^{69}$. Muchas veces, el castigo por haber realizado este acto fue el de mandar construir otras tantas cruces como compensación, como si de este modo se solucionara el problema, sin atender a las causas teológicas que produjeron el atentado. Dicha solución la vemos en el caso de Miguel, Luis Rebollo y Joan Cigueba de Zaragoza que en 1574 fueron condenados a que "se hiciese a su costa y de otros que parecieron culpados en el caso un humilladero y cruz nueva en la parte donde estava la otra con quatro pilares y cubierta" ${ }^{\prime 70}$. Castigo repetido en el proceso a Pedro Gómez de Riodena, cristia-

65. Borja FRANCO LlopIS, Espiritualidad, reformas y arte en Valencia (1545-1609), Barcelona, pp. 569589. Edición on line: http://www.tesisenxarxa.net/TESIS_UB/AVAILABLE/TDX-1030109-134228// FBFLL_TESIS.pdf. También se encuentra en imprenta un texto, fruto de la presente investigación, que aborda este hecho. Véase Borja FRANCO LLOPIS, «En defensa de una identidad perdida: los procesos de destrucción de imágenes en Valencia durante la Edad Moderna», Goya: revista de arte, 335, 2011, pp. 116-125.

66. En otros trabajos hemos estudiado el uso de la cruz en las predicaciones y su sentido dentro de la multiculturalidad imperante en el siglo XVI. Véase Borja FrANCO LLOPIS, Espiritualidad, reformas y arte..., pp. 501-514 y, del mismo autor, «Apuntes sobre el uso votivo y misional de la cruz en el arte valenciano de la Edad Moderna», en VVAA, Cartografías visuales y arquitectónicas de la Modernidad, siglos XV-XVIII, Barcelona, 2011, pp. 243-257.

67. AHN. Inquisición. Leg. 2022. Núm. 13, 1583.

68. “En la qual senda havia dos cruzes largas clavadas en la tierra [...] el más pequeño de los hermanos [...] tiro de la espada corta que traía en el costado y tiró de rebés una cuchillada a la cruz que havia que la hechó sieto u ocho passos por tierra", AHN. Inquisición. Leg. 549. Núm. 14, 1573.

69. " $[. .$.$] que viniendo con otros moriscos por un camino topo una cruz derribada en tierra y$ dixo que si esta tuviese algun poder ella se levantaria que lo dixo asi porque no creya lo que dicen los cristianos de al cruz y porque estaba entonces en la secta de Mahoma", AHN. Inquisición. Lib. 988, 1540-1581, s. p.

70. Ibídem. 
no nuevo, que "por haver arrincado dos cruzes de madera que estavan puestas en dos caminos reales y las quito de alli y puso en un rincón fuera del camino real y quando passo lo susodicho hiba con una requa en compañía de otros arrieros y alto tocado del vino, vela, soga, desterrado del dicho lugar dos meses precisos, abjuracion de lengua y que a su costa se hagan dos cruzes de madera con sus pies de piedra las quales se pongan donde estavan las otras"71.

Pero no todos los procesos nos mostraron ataques a las imágenes por motivos religiosos, es curioso el caso del francés Arnautet e Peyberryt que se encargó de destruir las cruces de la ermita y las que había de camino a la misma porque no le dieron alojamiento como peregrino ni allí ni en otro de los monasterios de la ciudad. Ciertamente, la procedencia del reo nos hace dudar que fuera un simple enfado o que no tuviera un trasfondo religioso oculto, pero, de todas maneras, no deja de ser interesante su razonamiento, basado en la ira y la impotencia de quedarse sin techo para esa noche, como el motivo del destrozo $^{72}$, atentando, pues, contra los símbolos que caracterizaban aquellos hospicios donde no le atendieron misericordiosamente.

Tampoco las imágenes de la Virgen se libraron del acoso de los insurrectos. En este caso debemos anotar que fueron llevados a cabo, mayoritariamente, por extranjeros de ideología luterana y no por moriscos, como sucedía con las cruces. Este hecho es significativo y proviene de la propia ideología del citado grupo religioso. Los musulmanes creen en María como madre de Jesús y ejemplo de vida, de ahí que no atentaran sistemáticamente contra ella; por el contrario, los protestantes entienden su reverencia como un signo más de idolatría y de politeísmo que impide el verdadero culto a Dios. A todo ello debemos unir el citado hecho de que los autores procedieran, casi en su totalidad, del extranjero, ya que es conocida la gran devoción mariana que se profesaba en territorio hispano, lo que pudo suponer una actitud menos beligerante de los iconoclastas nativos hacia su figura.

Un ejemplo de ataques contra representaciones marianas lo podemos encontrar en el proceso contra Jaques Juan Amaral, flamenco vecino de Cádiz que "andubo en habito de ingles con los demas ingleses quando maltratavan a los altares e ymagines y les ayudo a ello y dio de cuchilladas a cierta ymagen de

71. AHN. Inquisición. Lib. 937, 1587-1595, s. p.

72. "Fue testificado que visto por un testigo mayor cristiano viejo dar de palos a una cruz y a las insignias de la passion que estavan en ella a la puerta del Monasterio de Jesús de la ciudad [...] el Vicario y otro religiosso del convento subieron y vieron los passos derribados por el suelo [...] confesso que havia dado de palos a la dicha cruz [...] haviendo llegado de noche buscando possada y no se dando [...] y habiendo llegado a una hermita y no quieriendo acogerle volvio al lugar en el qual le volvieron a enviar a la hermita y volviendo segunda vez alla tampoco le quisieron acoger, que enojo de esto tiro con unos yesones a una cruz que estava junto a la dicha hermita y hecho en el suelo otra que havia en el camino lo qual todo hizo con enojo y no por entender que a las cruzes no se deva reverencia y quitarles el sombrero como siempre lo ha hecho", AHN. Inquisición. Lib. 990, 1596-1608, s. p. 
Nuestra Señora"73. O, también, en el de Antón de Fuertes, Francisco Ruidrez y Jayme Veza, franceses residentes en Zaragoza que "donde posaron se hallo que en una cortina de lienço en que havia una ymagen de Nuestra Señora con su Hijo Jesucristo que estava en la estancia donde se vio [...] en el rostro y otras partes de la ymagen havia ciertos agujeros que parecian puñaladas" ${ }^{\prime 7}$. El mismo caso se repitió, por citar otro ejemplo de distinto ámbito geográfico, en el proceso de Baena de Pedro Torrejabano que "testificaronle tres testigos de que echando mano a la espada, quiso dar una cuchillada a una imagen de Nuestra Señora que estaba fijada en la pared y le reprendieron y fueron a la mano para que no lo hiciese, y otro dia tornandole a reprender, dijo que Nuestra Señora estaba en el cielo, que aquel era un poco de papel y con una daga le dio una puñalada"75.

Más curioso aún fue el proceso contra Juan de la Cam, natural de Gascón, que no se centró en destruir la imagen mariana sino en quererla 'violar' ya que afirmó, en respuesta a las palabras de una fiel que hablaba de la belleza de la representación que "yo me la quiero traer y la cabalgare en el macho y me la jodere por el camino"76. En este ejemplo más que hablar de una respuesta identitaria relacionada con el grupo religioso al que pertenecía el reo debemos hablar de un comportamiento más cercano al desequilibrio mental que se materializó en estas desafortunadas palabras.

Si bien hasta aquí hemos expuesto actos aislados contra imágenes, relacionados bien con la ideología iconoclasta morisca, protestante o con desequilibrios mentales puntuales, la mayor parte de la documentación consultada nos presenta verdaderas masacres de conjuntos artísticos similares a aquellos realizados en territorio galo y germánico en este mismo periodo. De hecho, al igual que ocurriera con el caso mariano, la mayor parte de ellos procedían de dichos territorios o incluso de Portugal y lo que hicieron no fue más que trasladar sus costumbres a nuestro país con el fin de imponer su ideología. Además, en paralelo a esta actitud protestante, tendríamos las diversas revueltas moriscas donde arrasaron con todo lo que encontraron a su paso, principalmente con aquellos símbolos de la opresión católica. Tal fue el caso de Joan Sanchez, que fue testificado porque "dixo que avia andado en la guerra de este reyno [de Granada] y se avia hallado en quemar muchas ymagenes de santos y avia publicado que los moriscos las avian quemado y esto nego el reo" ${ }^{\prime 77}$. Este hecho se repitió en la acusación a Diego de Rojas "que levantó los moriscos del Alpuixarra y del reyno de Granada contra la fee católica de Nuestro Señor Jesucristo y contra la Majestad

73. AHN. Inquisición. Leg. 2075. Núm. 10, 1599.

74. AHN. Inquisición. Lib. 988, 1540-1581, s. p.

75. AHN. Inquisición. Leg. 1856. Núm. 21, 1587. Citado también en José María GARCía FuENTES, op. cit., p. 213.

76. AHN. Inquisición. Lib. 988, 1540-1581, s. p.

77. AHN. Inquisición. Leg. 1953. Núm. 15, 1582. Transcrito en José María García FuENTES, op. cit., p. 274. 
real para ser moros y predicar la secta de Mahoma y profanar iglesias y quemarlas" $^{\prime 78}$. O, por último en el de Costança López, "porque quando se levantaron los moriscos, mostro tener gran contento y tenia en su casa debaxo de su estrado donde se asentava el ara consagrada de la iglesia quebrada y en su casa se quemava por leña la madera del retablo de la dicha iglesia"79.

De todas maneras, no podemos exponer que sólo se redujeran estos destrozos multitudinarios de imágenes por parte morisca a las batallas o revueltas. También poseemos casos particulares, cuyo ejemplo podría ser el de Matheo Sánchez, vecino de Granada que se encargó de destruir todas las imágenes de Cristo y de los Santos de la Iglesia de su ciudad ${ }^{80}$, siguiendo el patrón que sus hermanos de fe utilizaron en los ataques iconoclastas.

Estos sucesos, como dijimos, tuvieron su correspondiente análogo en los atentados realizados por la facción protestante en territorio hispánico. Curiosamente son varios los llevados a cabo por portugueses, sobre todo en la zona andaluza, donde Francisco de Antequera, natural de Lagos en territorio luso “avia puesto diversas cruzes debaxo de su suciedad de persona, y que havia cortado con un puñal tres cruzes de papel y las avia quemado y otra imagen de un santo, y a otra cruz pintada la avia dado con un puñal seys o siete rasguños, y que havia quemado un Cristo de plomo en la fragua por quemar la semejanza de Cristo, y que se avia ensuciado en una cruz y en una ymagen de nuestra Señora de papel, y que una una ymagen de madera con el niño Jesús avia dado tres cuchilladas por la mitad del rostro, y otras muchas cosas desta suerte [...] y también avia ensuciado dos ymagines de nuestra Señora que estan en lugares proximos de cordova de que se siguió muy grande escandalo, y que tenia pensado de comprar un Cristo de papel con Nuestra Señora y San Juan a los lados y ensuciarse en el $^{\prime 81}$.

Algo muy parecido realizó su compatriota Francisco de San Juan, franciscano natural de Lamego, que se reafirmó como luterano tras convertirse en Bretaña y que por ello apoyaba a los que "quando entraban en las Iglesias hacian pedaços las ymagenes y cruces dandoles de cuchilladas y quemandolas, y alla en nuestra tierra, no hacemos caudal de los sanctos, y ansi como llegamos a las Iglesias donde estan los cortamos las cabeças y los arrimamos a un rincón y a las cruces hacemos pedazos" ${ }^{82}$.

Así, pues, podemos comprobar cómo fueron estos inmigrantes, previo paso por el extranjero, quienes importaron esta violencia contra las imágenes y no se ocultaron en exponerlo. Pero no sólo ellos, sino también ocurrió con los

\footnotetext{
78. AHN. Inquisición. Leg. 1953. Núm. 5, 1571. Transcrito en José María GARcía FuENTES, op. cit., p. 100.

79. Ibídem, p. 114.

80. Ibídem, p. 254.

81. AHN. Inquisición. Leg. 4972. Núm 2, 1578.

82. AHN. Inquisición. Leg. 2022. Núm. 22, 1592.
} 
franceses de Bearne que vivieron en la diócesis de Zaragoza ${ }^{83}$ y en Valencia, cuya actitud beligerante se saldó con diversos actos iconoclastas con el fin de reivindicar su postura religiosa. Por ejemplo, Beltrán de la Borda, vecino de Zaragoza, fue apresado en 1588 porque "muchos testigos le oyeron dezir que no sabia que virtud tenian los santos que bien se dexaran quemar y se avia hallado a quemar dos carretadas dellos y quando en Bearne se alçaron los luteranos andubo con ellos en guerra dos años y en aquel tiempo sacaron de una iglesia una ymagen de Sant Antón y le dezian que hiziese milagros o que la hecharian al fuego, y como vieron que no los hazia la quemaron [...] y tratando de una persona que tenia amistad con otras que hazien ymagenes de sanctos, dixo (como burlandose) que para que tenia amistad con aquellas personas y las favorecía siendo quitones y que hazian sanctos y nonadas que pues ellos hazian sanctos, que por que los sanctos no les ayudarian" ${ }^{84}$. Lo mismo que defendiera Antonio Joan, de la misma zona, pero esta vez ante el tribunal valenciano ${ }^{85}$.

Como conclusión a este breve recorrido por algunos casos significativos de la iconoclastia hispana que nos depara el estudio de los procesos inquisitoriales, podríamos reseñar principalmente un motivo: la defensa de su ideología ante la postura monolítica católica. Unos, los moriscos, respondieron a ataques más o menos organizados, como en las Alpujarras, para destruir todos aquellos símbolos de la opresión, principalmente cruces, pero siempre de un modo más o menos organizado, no de manera indiscriminada, sino atendiendo a su ideología, de ahí que no atentaran contra imágenes marianas. Por otra parte, la facción protestante provenía, en su mayoría, del extranjero y actuaron siguiendo el mismo modus operandi que habían observado en sus países de origen, no distinguiendo entre unas u otras representaciones artísticas, ya que todas eran símbolo de idolatría y por ello debían ser destruidas.

Antes de finalizar, quisiéramos aportar otra noticia inédita que creemos es de sumo interés para el estudio de la cultura y arte en nuestro territorio. Fontcuberta en su tesis doctoral ${ }^{86}$ anunciaba que era una lástima encontrar muy pocos ejemplos de arte crítico en España, de esas representaciones animalísticas del Papa o de los reformadores, que sí que se reprodujeron en los Países Bajos. En uno de los textos inquisitoriales consultados encontramos una de las escasísimas referencias a este hecho. Nos referimos al proceso, hasta ahora,

83. Para un estudio detallado de los casos de iconoclastia en esta diócesis véase Borja FrANCO LLOPIS, «Noticias sobre arte y devoción del Quinientos aragonés a través de la documentación inquisitorial», en Boletín del Museo e Instituto Camón Aznar, 107, 2011, pp. 61-76.

84. AHN. Inquisición. Lib. 989, 1582-1596, s. p.

85. “Digo que el a ydo con compañía de luteranos abra nueve años, y andubo en su compañía dos meses en una cuaresma a los quales veya quebrar las ymagenes y derrivar las yglesias y las cosas que Rovaban las davan a este para que las llevase [...] esta con los luteranos contra los catholicos con armas derrivando las yglesias y quebrando las ymagenes, haziendo todo lo de mas que los luteranos hazian contra los católicos", AHN. Inquisición. Leg. 530. Núm. 16, 1572.

86. Cristina Fontcuberta FAmadas, L'art crític a l'Época Moderna. Condicions de producció, difusió $i$ recepció. Tesis doctoral inédita defendida en la Universitat de Barcelona, 2001. 
como señalamos, inédito, celebrado en 1575 por Joan Gorgoll, natural de la Villa de Palamós, perteneciente al obispado de Girona, en el cual se narra cómo "estando jugando a los naipes unos les dixeron que les daria otros mejores que havia traydo de Francia y los traixo, los quales estavan figurados de figuras en innomia del pontifice y nuestra religión porque en el uno havia pintado un papa y en el otro una muger con un titulo que dezia esta es la papesa y en otro una yglesia ladeada como que se queria caher y los de copas era una custodia y las demas un caliz con una ostia ensima" ${ }^{87}$. Podemos ver, pues, cómo se nos habla de las típicas estampas en burla de la religión católica que el reo había importado del país vecino, donde su producción, así como los grabados con dicho tema, estaban a la orden del día. Era, pues, otro modo de difundir las ideas que tuvo mucha importancia en el desarrollo de la reforma protestante y que aquí podemos ver documentado, siendo, como dijimos, uno de los pocos ejemplos, si no gráfico, ya que la mayor parte de ellos se perdieron, sí escrito de la existencia y llegada de las mismas a nuestro territorio.

En conclusión, en este artículo hemos tratado de mostrar diversas noticias, entre las múltiples posibles, relacionadas con el uso de la imagen en el siglo XVI tanto en defensa como en oprobio de la fe, como muestra de una identidad o rebeldía o, todavía más importante, realizar una aproximación a la teoría artística no partiendo de los grandes tratados, sino de las cuestiones más cotidianas, de las dudas que tenía el pueblo y que muchas veces degeneraban en herejía, convirtiéndose entonces en objeto de condena. Creemos que los procesos inquisitoriales, a pesar de ser una fuente bastante subjetiva, nos sirven para cumplir este objetivo y reinterpretar la concepción de la imagen como elemento matérico, la idea de latría o las razones y luchas de fe que llevaron a su destrucción, completando, con ello, el conocimiento que a día de hoy tenemos del entramado histórico artístico sumamente complicado de la Edad Moderna en la Península Ibérica. La imagen como elemento multicultural, como epicentro de un problema social, de la inestabilidad religiosa, como piedra de toque en las relaciones entre protestantes, moriscos y cristianos viejos. Una visión que ya Epalza intuía en los consejos que nos incitaron a emprender este estudio y que en estas páginas, de modo sintético, tratamos de exponer.

\section{ABREVIATURAS}

AHN Archivo Histórico Nacional, Madrid.

ARSI Archivum Romanum Societatis Iesu, Roma.

BL British Library, Londres.

BNM Biblioteca Nacional, Madrid.

87. AHN. Inquisición. Lib. 730, 1540-1585, f. 193 v. 


\section{RESUMEN}

En este artículo abordamos el estudio de las imágenes durante el siglo XVI en territorio hispano a través de las fuentes inquisitoriales. Buscamos conocer cómo se utilizaron en dicho periodo, cuáles fueron sus funciones, cómo fueron recibidas por el pueblo (fueran moriscos, protestantes o cristianos viejos, que convivieron en dicho territorio), qué problemática entrañó su culto y cómo su destrucción fue una muestra de la rebeldía de los grupos disidentes por imponerles una ideología que les era ajena. Esta información, mayormente inédita y conservada en el Archivo Histórico Nacional de Madrid, la compararemos con diversas obras coetáneas con el fin de presentar una nueva aproximación al estudio del arte moderno hispánico, mostrando cómo el arte es una forma primordial para adentrarnos en el universo multicultural de dicho periodo.

Palabras clave: arte, moriscos, protestantes, Inquisición, iconoclastia, reforma católica.

\section{ABSTRACT}

This article presents the study of images, during the $16^{\text {th }} \mathrm{C}$ in Spanish territory, through inquisitorial sources. The purpose is to know how these images were used in the period, which were their functions, how were they received by the people (were they Moriscos, Protestants, or "old Christians" living in the territory), which problems were associated to their rites and how their destruction became a demonstration by the dissent groups of rejection for an alien ideology. The information, mostly unpublished and preserved in the National Historic Archive of Madrid, is compared to contemporary works, to present a new view on the study of Spanish Modern art, demonstrating how art is an essential form of understanding the multicultural universe of the period.

Key words: art, Moriscos, Protestants, Inquisition, iconoclasm, Catholic reformation. 